\title{
РЕПРЕЗЕНТАЦІЯ НОМЕНА В ТРАНСПОРТНОМУ ДИСКУРСІ
}

\author{
НЕЛЯ НІКУЛІНА \\ Харківський національний автомобільно-дорожній університет, \\ Харків - Україна \\ REPREZENTACJA LEKSYKI \\ W DYSKURSIE TRANSPORTOWYM \\ NELIA NIKULINA \\ Charkowski Narodowy Samochodowo-Drogowy Uniwersytet, \\ Charków — Ukraina
}

STRESZCZENIE. Artykuł poświęcony jest funkcjonowaniu nomenklaturowego znaku w specjalistycznej komunikacji przedstawicieli branży transportowej. Wyodrębniono pozabranżowe zakresy używania jednostki nomenklaturowej, określono jej kulturologiczne i dyskursywne właściwości.

\section{REPREZENTATION OF A NOMEN IN TRANSPORT DISCOURSE}

\section{NELIA NIKULINA}

Kharkiv National Automobile and Highway University, Kharkiv — Ukraine

ABSTRACT. This article explores the functioning of a nomen (a nomenclature sign) in transport industry professional communication. The use of a nomenclature unit beyond the range of this professional field is highlighted. The culturological features and discourse characteristics of a nomenclature unit are determined.

$\mathrm{H}$ а сучасному етапі розвитку українського термінознавства на особливу увагу заслуговує проблематика фахової дискурсивної практики, а саме вживання термінологічних одиниць і номенклатурних знаків у професійній комунікації представників різних галузей науки й техніки. Однак не менше зацікавлення у термінологів різних країн світу викликає й позафахове вживання наукової лексики, зокрема в рекламному дискурсі.

Метою статті є дослідження параметрів функціонування номена (номенклатурного знака) в професійній комунікації представників транспортної галузі. У межах цієї наукової розвідки також виокремлено позапрофесійні сфери вживання номенклатурної одиниці, визначено ії культурологічний потенціал, функційні особливості й дискурсивні властивості.

Задекларована наукова проблема належить до малодосліджених: до цього часу не розглядалися дискурсивні практики в межах українського транспортного термінознавства. Та й сама проблематика фахового дискурсу та його механізмів лише частково досліджені в українському й зарубіжному мовознавстві.

Актуальність статті полягає в дослідженні комунікативного поля усного й писемного вживання номенів фахівцями від транспортної галузі (професій- 
ний дискурс), залучення транспортних номенів у сучасні прозові твори (художній контекст), а також залучення номенклатурних одиниць до створення рекламного продукту (рекламний дискурс).

Дискурс неодноразово був об’ єктом дослідження мовознавців різних країн світу: Маріанне В. Йоргенсен (Данія); Тен ван Дейк (Голландія); Луїза Дж. Філліпс (Швеція); П. Серіо (Франція); М. Макаров, В. Карасик, Н. Зяблова, Ю. Степанов, О. Русакова (Росія); Ф. Бацевич, І. Шевченко, К. Кусько, Г. Почепцов (Україна).

3 огляду на те, що в сучасному українському й зарубіжному мовознавстві термін дискурс уживається з різним трактуванням, у цьому дописі розглянемо кілька, як на нашу думку, домінантних поглядів учених.

Голландський лінгвіст Тен ван Дейк уважає, що „дискурс — це зв’ язана послідовність писемних пропозицій або усних висловів, повідомлених у певній комунікативній ситуації з метою трансформації певної інформації або виконання інших соціальних дій"

На думку російського вченого Ю. Степанова, „дискурс — це „мова в мові”, але подана у вигляді особливої соціальної даності. Дискурс реально існує не у вигляді своєї „граматики” й свого „лексикону”, як просто мова. Дискурс існує передусім і головним чином у текстах, але таких, за якими постає особлива граматика, особливий лексикон, особливі правила слововживання й синтаксису, особлива семантика, — врешті-решт - особливий світ. У світі дискурсу діють свої правила синонімічних замін, свої правила істинності, свій етикет. Це - можливий (альтернативний) світ"2.

На увагу заслуговує й широкоаспектне означення дискурсу ще одного російського науковця Н. Зяблової, на думку якої, дискурсом слід уважати вироблену в певних історичних і соціальних рамках, інституційно організовану й тематично сфокусовану послідовність висловів, що конструюються відносно певної мети й розв’язку відповідних проблем, рецепція яких здатна вплинути на моделі суб'єктивного досвіду людини, її внутрішню репрезентацію світу, переконання й поведінку ${ }^{3}$.

Однак в основу нашого трактування дискурсу покладено дефініцію, сформульовану в довідковому виданні Словник термінів міжкультурної комунікації українським мовознавцем Ф. Бацевичем: „Дискурс (фр. discourse - pозмова; $<$ лат. discursus - розмірковування) — тип комунікативної діяльності, інтерактивне явище, тривалий у часі процес, утілений у певній (іноді значній) кількості повідомлень; мовленнєвий потік, що має різні форми вияву (усну, писемну, друковану, паралінгвальну тощо), відбувається в межах одного чи кількох каналів комунікації, регулюється стратегіями і тактиками учасників спілкування і являє собою складний синтез когнітивних, мовних і позамовних (соціальних, психічних, психологічних тощо) чинників, які визначаються конкретним колом „форм життя”, залежних від тематики спілкування. Дискурс має своїм результатом формування різноманітних текстів і мовленнєвих жанрів"4.

\footnotetext{
${ }^{1}$ О трендах в дискурсном подавлении, европейском национализме и гуманитарной ядерной бомбе, [в:] Электронный pecypc: http:// discourseanalysis.org/ (12.01.2013).

2 Ю. С. Степанов, Альтернативный мир, дискурс, факт и приниип причинности, [в:] Язык и наука концฺа ХХ века, Сборник статей, Москва 1995, с. 44.

${ }^{3}$ Н. Н. Зяблова, Дискурс и его отличие от текста, [в:] „Молодой ученый” Казань 2012 , № 4, c. 223-225.

${ }^{4}$ Ф. С. Баце в ич, Словник термінів міжкультурної комунікації, Київ 2007, с. 205.
} 
У вказаному науково-довідковому виданні окрема стаття присвячена поняттю національний дискурс, що визначається автором як вербалізована мисленнєво-мовленнєва діяльність, яка розуміється як сукупність процесів, що мають як лінгвістичний, так і екстралінгвістичний плани і здійснюються представниками конкретної національної лінгвокультурної спільноти з використанням їхньої ідіоетнічної (рідної) мови 5 .

Очевидно, Ф. Бацевич для розв'язання наукової проблеми дефінування терміна дискурс опирається не лише на лінгвістику, а й на філософію, культурологію, психологію, етнографію, літературознавство, а також бере до уваги наявність у багатьох дискурсах професійно-комунікативної компетенції.

Саме про презентацію професійно-комунікативної компетенції через уживання номенів (номенклатурних знаків) в українському транспортному дискурсі й ітиметься далі в цій науковій розвідці.

3 огляду на те, що в українському й зарубіжному мовознавстві немає єдиної традиції в називанні номена (учені вживають в одній науковій статті по кілька найменувань). Авторка цієї статті пропонує ввести номінацію технічний номен і залучити до цієї групи транспортні номени.

Отже, технічний номен - це спеціальна ідентифікаційна одиниця термінологічної системи, що називає конкретний одиничний об'єкт, конкретний зразок чи серію предметів масового виробництва й репрезентує номенклатуру певної галузі науково-технічних знань. У формулювання можна додати, що техномен є стислою проекцією дефініції термінологічної одиниці й основних технічних характеристик об'єкта науки, що переважно передається власне терміном чи абревіатурою з додаванням символьної чи цифрової частини або ж онімів $^{6}$, напр., у транспортній термінологічній мегасистемі, що належить до технічної галузі знань, найбільше номенів (номенклатурних знаків) побудовано за вказаною формулою: ГАЗ-24 „Волга” — легковий автомобіль Горьковського автомобільного заводу, 24 модель, сімейство „Волга”; TE-0,25 - таль електрична, вантажність 0,25 т; KA-10 - кран автомобільний, 10 модифікація; BB-350візок вантажний, вантажність 350 кг; КП-55 - конвеєр пластинчастий, продуктивність 55 т/годину; ВШ-400 — візок-штабелер, вантажність 400 кг.

Досліджуючи номенклатурну систему авіаційної лексики, що належить до транспортної термінологічної мегасистеми, Л. Корженська (Халіновська) вводить поняття авіаонім і виокремлює такі різновиди номенів: 1) номени на основі патронімічних назв різних серій перших аеропланів: „Полікарпов”, „,Фарман”, „Ньюпор”, „Кудашев” та ін.; 2) номени, що походять від імен: а) міфічних героїв, напр., „Антей” (літак, один із найбільших у світі), „Аполон” (серія американських космічних кораблів), „Венера” (серія міжпланетних космічних апаратів); б) фольклорних персонажів, напр.: „ІІля Муромецьь”, „Руський Витязь” (багатомоторні важкі літаки); 3) номени відтопонімічного походження: „Харків”, „Прип'ять” (аеростати), „Київ” (дирижабль), „Омськ” (повітряна куля); 4) номенклатурні назви, що витворилися внаслідок перейменування назв на позначення: умовного птаха — „Орнітоптер” (пробна першоконструкція, крила якої рухалися в повітрі подібно до крил птаха); вигаданої істоти „Коник-горбоконик” (перший серійний цивільний літак); певного класу тварин — „Амфібія” (літак, пристосований для зльоту і посадки на суші й на воді);

${ }^{5}$ Там само, с. 10.

${ }^{6}$ Н. В. Нікуліна, Утилітарні вимоги до номена (на матеріалі транспортної термінологічної мегасистеми), [в:] “Проблеми української термінології” Львів 2012, № 733, с. 139-144. 
абеткових літер — „Омега” (вертоліт); біологічних субстанцій — „Ембріон” (перший запатентований апарат К. Данилевського); небесних тіл, планет „Марс” (серія автоматичних міжпланетних станцій); ,,Меркурій” (серія космічних кораблів $)^{7}$.

Зазначимо, що в основу багатьох моделей авіаційного номена на позначення транспортного засобу покладено прізвище авіаконструктора: Туполєв Андрій Миколайович (Ty-124 M, Ty-154, Ty-134 M); Іллюшин Сергій Володимирович (Іл-62, Іл-76 M, Іл-96); Яковлєв Олександр Сергійович (Як-40, Як-42); Антонов Олег Костянтинович $(A \mu-124, A н-72 / A н-74)$, тоді як номени залізничного транспорту, крім цифрової частини, мають у своєму складі власну назву, переважно назви фірмових потягів: „Славутич”, „Біла акація”, „Азов”, „Галичина”, „Троянда Донбасу”, „Либідь”, „Голубі озера”, „Східний експрес”, „Хаджибей”, ,Дніпровські зорі”.

У цій науковій розвідці транспортним номеном уважаємо спеціальну ідентифікаційну одиницю транспортної термінологічної мегасистеми, що об’єднує наукові поняття цілої низки галузей, пов'язаних 3 комплексом різних видів транспорту, які взаємодіють і перебувають у залежності під час здійснення перевезень. Структура транспортної термінологічної мегасистеми полягає в поділі на транспорт загального користування (залізничний, річковий, морський, автомобільний, повітряний, трубопровідний); промисловий транспорт (внутрішньоцеховий, внутрішньозаводський і зовнішній); спеціалізований пасажирський транспорт (трамвай, метрополітен, тролейбус), промисловий трансnорт (кліть, ліфт, канатна і монорельсна дорога) і транспорт особистого користування (легкові автомобілі, мотоцикли, яхти тощо). Розуміємо, що певного дослідження вимагає й сама побудова мегасистеми, iї структура й розчленування на підсистеми й мікросистеми, де не обов'язково є лише терміни й номени, що репрезентують види транспорту, а й номінації на позначення продукції (перевезення вантажів і людей), перебігу транспортного процесу та фахової діяльності. Отже, архітектоніка транспортної термінологічної мегасистеми потребує окремого дослідження й структурування.

Матеріалом основної частини статті є наукові та публіцистичні тексти 3 друкованих й електронних видань України, коментарі й дописи читачів Інтернетресурсів, що в комплексі можуть репрезентувати можливості номена в транспортному дискурсі.

Розгляньмо кілька фрагментів транспортних дискурсів, що вибрані з різних джерел і мають у своєму складі номени (номенклатурні знаки).

Найемоційніші користувачі мережі Інтернет транспортні номени використовують для характеристики певних подій, що склалися в суспільстві, адже для більшості українців пересування в межах великих міст залишається архіважливою проблемою. I тут номени допомагають створити своєрідний „портрет міста", напр., коментар читача до статті Трамваї та Київ. Транспорт, у якому застиг час: „Те ж саме про „жлобські маршрутки” - може вони й були такими якийсь рік-два, коли „Газелі” — душегубки змінилися „Богданами” і були рази в 2 дорожчі за трамвай, але зараз досить проїхатися в такій маршрутці в годину пік, щоби позбутися усього жлобства й оцінити перевагу трамваїв, особливо - швидкісного. Можна ще, звичайно, сказати, що рухляді не радянські, а чеські (більшість київських вагонів - справжні „Шкоди”), і ще багато де-

7 Л. А. Халіновська, Відонімічні назви у номенклатурній системі лексики на позначення „літальних апаратів”, [в:] “Ономастика і апелятиви” Дніпропетровськ 2001, вип. 14, с. 51-54. 
талей, але для чого? Маємо текст, написаний з душею, і за це щира подяка автору"8.

Бачимо, що автор допису через своє невдоволення транспортною ситуацією використовує автомобільний номен ГАЗ 2705 „Газель” у множині і з негативною конотацією „Газелі”-душегубки. Не менше невдоволення викликають „Богдани” національного автодилера „Богдан-Авто Холдинг”, у цьому разі негативна конотація пов'язана з ціною за перевезення. Отже, навіть спосіб уживання номенклатурних знаків може формувати ставлення мовців до технічної реалії, вказувати на технічні недоліки вітчизняної техніки.

Протилежну ситуацію прослідковуємо під час аналізу вживання номенів у тексті „Покращення”на залізниці. Люди на знак протесту рвуть білети 3 електронного видання TEXTY.org.ua: „Тернополяни не дочекалися нового „Хюндая”, проте на південь курсуватиме на 12 рухомих складів більше. Частина пасажирів, як пишуть в Інтернеті очевидці, на пероні рвала квитки на знак протесту. Вони були впевнені, що на маршруті буде потяг класу „, Інтерсіті” „Шкода” чи „Хюндай”. Так само думали і в столиці. Але такі потяги, як пояснюють залізничники, курсуватимуть хіба що на маршруті з Донецька, Харкова та Дніпропетровська до Криму"я.

Тут усе навпаки, назви залізничних номенів „Інтерсіті”, ,Шкода”, „Хюндай” (навіть попри масу нарікань через занадто дорогі квитки й часті поламки) викликають позитивну конотацію, адже асоціюються $з$ анонсованим комфортом: зручності салону, наявність стюардів, підвищена швидкість, безпровідний Інтернет, що так яскраво зображені в рекламі швидкісних потягів класу Інтерсіті+ південнокорейської компанії Hyundai Rotem.

Отже, функціонування транспортних номенів 3 емоційно-оцінною конотацією в дописах блогерів є соціальною характеристикою епохи, відображає психологічний і фізичний комфорт / дискомфорт громадян під час перевезень.

У виданні „Газета по-українськи” для поціновувачів автотранспорту є окрема рекламна рубрика Авто. Розглянемо два тексти цього науково-популярного Інтернет-видання:

1. „Салон „Бліц Авто” є офіційним дилером автомобілів марок „Kia”, „Опель”, „Шевроле”, ЗАЗ та „Чері”. Серед недорогих автівок — „ЗАЗ Сенс” вартістю від 56900 гривень та „ЗАЗ Віда” від 82 200. Із дорожчих — „Опель Астра” від 142500 гривень, „Шевроле Авео” від 129 700, „Кіа Ріо” від 130 400. У салоні постійно діють акції та знижки на популярні машини, в цехах установили сервісне устаткування - діагностичне обладнання Скан-100"10.

2. „Серед марок і моделей найаварійнішими є БMB, „Тойота Kaмpi”, „Ленд Ровер” і „, Мітцубісі Лансер”. Чорні та сірі машини погано видно на дорозі, а власники червоних дуже агресивно кермують. У найтяжчі аварії потрапляють чоловіки в чорних БМВ і жінки в білих ,,Лексусах”. Рідше за всіх ДТП

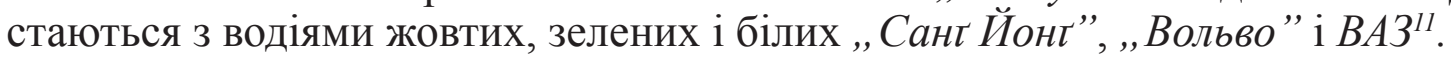

${ }^{8}$ Трамваї та Київ. Транспорт у якому застиг час, [в:] Електронний ресурс: http://texty.org. ua/pg/article/editorial/read/36967 (30.04.2013).

9 Покращення" на залізниці. Люди на знак протесту рвуть білети, [в:] Електронний ресурс: http://texty.org.ua/pg/news/movchun /read/46198 (21.03.2013).

10 За якістю українські автомобілі наздоганяють європейські, [в:] Електронний ресурс: http://gazeta.ua/newspaper/1619 (06.02.2013).

${ }^{11}$ У найтяжчі аварії потрапляють водї̈ чорних БМВ і водійки білих ,лексусів", [в:] Електронний ресурс: http://gazeta.ua/newspaper/1612 (09.01.2013). 
I в першому, і другому текстових фрагментах номени використано для маркування соціальної приналежності потенційних покупців автотранспортних засобів: автомобілі марки „ЗАЗ Сенс” і „ЗАЗ Biда” пропонують не надто заможнім верствам населення, а от „Опель Астра”, „Шевроле Авео”, „Кіа Ріо” можуть собі дозволити автомобілісти 3 дещо вищими статками. Навіть номени другого тексту, хоча йдеться не про цінові аспекти транспорту, приховано вказують на стереотипне мислення: сама марка БMB асоціюється 3 престижністю й високими технічними характеристиками, однак чоловіки в чорних БМВ уявляються українцям переважно представниками злочинних угрупувань чи силових структур. Жінки в білих ,лексусах”, незважаючи на „чистоту” білого кольору та ознаки матеріального успіху, також далеко не завжди викликають повагу в пересічного громадянина, оскільки асоціюються зі стереотипним образом коханки.

3 огляду на поданий вище аналіз двох текстів „Газети по-українськи”, можна констатувати, що номени (номенклатурні знаки) є часткою фонових знань і підставою для багатьох стереотипів, причому конотація сформованих стереотипів аж ніяк не впливає на трасформацію реалії, що репрезентована транспортним номеном.

Разом із тим, зазначимо, що функціонування номенів поза фаховим контекстом призводить до формування новотворів розмовно-побутового стилю, зокрема в мовленні автоспільноти зафіксовано такі неофіційні (сленгові) назви до номенклатурних знаків на позначення модифікацій автомобіля: автомобіль ВАЗ 2101 — копійка, автомобіль марки ВАЗ — ТАЗ, автомобіль 3АЗ 968М задорожець, автомобіль ЗАЗ-1103 „Славута” - сволота, автомобіль марки „Mercedes-Benz” - мерин, автомобіль марки BMW - беха, автомобіль німецького концерну „Volkswagen” — фолькс, a ,Volkswagen Golf” — гольф $a^{12}$.

Номінації автомобільного транспорту зустрічаються у творах сучасних письменників, напр., у романі С. Жадана Депеш Мод: боєздатний жигуль; мінтовський бобік; біла волжана ${ }^{13}$. Однак найбільше номенклатурних назв (номенів) і автомобільних жаргонізмів уживає Ю. Андрухович у романі Дванадиять обручів: міні вен, TIR, ролс ройс, мерседес, фольксваген, лада, шкода, опель, форд, ситроєн, волга, джипої, лімузин, драбадан ${ }^{14}$. Якщо Ю. Андрухович про автомобілі пише переважно в жартівливо-знижувальному негативному тоні, то М. Гримич у романі $E$ lö̈ $\mathrm{cm}^{15}$ на позначення марок автомобілів використовує номени з суфіксальними морфемами позитивного стилістичного забарвлення: опельочок, хондочка, що в такому контексті набувають властивих комунікативним одиницям ознак експресивності й модальності.

Для всіх наведених вище прикладів виходу номена з офіційної сфери наукового стилю притаманна одна й та ж тенденція - спрощення форми номенклатурної одиниці, виведення з усного транспортного дискурсу абревіатур і переосмислення первинних значень через посилення образності новотворів.

На особливу увагу заслуговує лінгвокультурологічний аспект побутування транспортних номенів, адже мова й культура — взаємопов'язані об'єкти, що об'єднані наявністю національних маркерів. Номени багатьох технічних транспортних реалій створюються штучно, а символічна значущість цих назв ви-

12 Форум автомобілістів, [в:] Електронний ресурс:http:/www.volkswagen.lviv.ua/forum/ archive/index.php/t-1896.html (13.03.2012).

${ }^{13}$ С. В. Жадан, Депеш мод, Харків 2004, с. 229.

${ }^{14}$ Ю. І. Андрухович, Дванадияять обручів, Київ 2003, с. 276.

${ }^{15}$ М. В. Гримич, Eıоїст, Київ 2006, с. 324. 
кликана не стільки технічними характеристиками виробів, як гордістю за потужний науково-технічний потенціал України.

На сайті, що має доволі красномовну й патріотичну назву „Зроблено в Україні" "16 йдеться про позитивні зрушення в українському виробництві, вже відомі широкому загалу, а також нові наукові відкриття й досягнення. Зробивши вибірку заголовних статей, опублікованих на цьому електронному ресурсі, можна виокремити доволі цікаві номінації: двигун „Люлька-Сатурн”АЛ41Ф, літак з крилом зворотної стрілоподібності Су-47 (C-37) „,Беркут”, бункер наземний перевантажувальний „Ковчег” БНП-12, трамвайний вагон моделі Т-3UA-3 „Каштан”, човен „Анна Ярославна”, ракетний крейсер „, Україна”, корвет „Хмельницький”, корвет „Придніпров'я”, розвідувальний корабель „Славутич”, нова модифікація вертольота „МСБ-2” (,Мотор-Січ-Богуслав”), корвет „Тернопіль”, розвідувальний корабель „Переяслав”, десантний корабель „,Костянтин Ольшанський”, військовий корабель „Чорноморещь”, корвет „Володимир Великий”, катер „,Орлан”.

Національно орієнтована визначуваність складників номенів на кшталт „Україна”, „Беркут”, „Анна Ярославна”, „Хмельнищький”, „Володимир Великий” свідчать про їх культурологічний потенціал і можуть слугувати джерелом знань про культурно-соціальний та історичний простір України.

Отже, транспортний дискурс (як писемна, так і усна форми) $є$ частиною комунікативного поля українців, механізмом, що впливає на формування думки про фахівця (професійний дискурс) і моделювання соціального статусу особистості (позафаховий рекламний дискурс).

16 Зроблено в Україні, [в:] Електронний ресурс: http://produced.in.ua (12.11.2012). 